Edwin Carels

\title{
From the ossuary: animation and the dance macabre
}

\begin{abstract}
'Cinema has long been a skeleton at a feast, but at the same time, as in a phantasmagoria program, a Méliès trick or a Disney cartoon, cinema is also a feast of skeletons, a carnival which simultaneously acknowledges our progressive loss of shared realities and provides a festive ground on which this loss can be anticipated, celebrated, mourned and perhaps even transcended. There is still a future, even if only an apocalyptic one, for this century-old illusion'.
\end{abstract}

(Tom Gunning)

In I995, the year film historian Tom Gunning published his essay on the 'forgotten future' of the cinema he was one among many theorists and cinephiles who met the centenary of the medium with great ambivalence. ${ }^{\mathrm{I}}$ At the moment when all aspects of the industry were gradually becoming aware of the challenges implied in digitisation, looking back at hundred years of film production felt almost as if turning one's back to the future and acting out of sync with the coming generations. In hindsight, we have to acknowledge that the impact of digital technology has indeed seriously affected the production and distribution of both mainstream and artist's cinema, in a much more radical way than even Gunning had anticipated with his focus on television and video technology. But in spite of the fact that digital technologies are effectively replacing filmstock at both ends, the legacy of cinema globally remains an important shared framework, and the dissemination of its cultural history has never been as great. Cinema is migrating and mutating and so is its public, but the experience of sharing this audio-visual legacy remains a significant cultural phenomenon. Cinephilia is not what it used to be, but it did survive these transmutations, and it is still being rejuvenated. Or perhaps one should rather say: reanimated?

If the future now appears less 'apocalyptic' then anticipated, over the last two decades, the film lover's bible did undergo serious rewrites, particularly in its first chapters. The genesis of the cinema is now commonly situated as much earlier than I895. In his essay, Gunning hints at a comparison between the chaotic present of the audiovisual industry and the creative unrest at the end of the nineteenth century. His intuition about the importance of the prototypes of cinema (the magic lantern, phantasmagoria, optical toys, in short: the animated image before the cinema) meanwhile has been absorbed in both theory and practice. ${ }^{2}$ The more we integrate new media into our daily interaction with moving images, the more those older media reveal their significance as prototypes or harbingers of different modes of engagement 
with the audio-visual. Without properly addressing the pervasive effect of computer graphic animation in all sorts of contemporary media (the main nemesis at the time of his writing was still video technology), Gunning had already shifted the attention from the photorealistic to the animated quality of movement. The real ambivalence at the core of his argument, is a recurring mediation between representational realism and a phantom-like appearance throughout the evolution of audiovisual technologies.

The following text takes as a starting point the final sentences of Gunning's essay, quoted above and develops his allusions and metaphors further using iconology as a framework, paying particular attention to the visual motif of the skeleton. The concept of iconology initiated by the German art-historian Aby Warburg (I866-I929) in the first decades of the 20 th century, was developed further by his direct successors into a more iconographic method, focussing on the specific content of static images, rather than continuing the dynamic interpretation of visual motifs throughout different epochs. The idea of the migration of motifs, the so-called Nachleben of images, was a central concept in Aby Warburg's theory of the dynamics of continuity, tracing pictorial meaning throughout time and space. ${ }^{3}$ Recently, art-historians such as Georges Didi-Huberman and Philippe-Alain Michaud have been reappraising Warburg's migratory ideas from a more contemporary perspective, applying a strong awareness of the parameters of cinema: ${ }^{4}$

'Even before it can be considered a technological and spectacular apparatus, the cinema is a way of image thinking. That is how in the first two decades of the 2oth century, Aby Warburg invents in art history, far from the industrialisation of the cinema and its transformation in mass culture, a style of analysis of images founded on the characteristics of montage and of the unwinding, that would find at the end of the twenties, in the unfinished project of Mnemosyne, its ultimate elaboration: the series of Pathosformeln that Warburg projects on the panels of his Atlas are cinematographic objects - story-boards of his thinking' ${ }^{5}$

Didi-Huberman, and more particularly Michaud elucidate the cinematographic qualities that Warburg largely intuitively implicated in his art historical approach. The reverse is also worth investigating, and is the central research question of this text: to what extent is the iconological approach of Warburg applicable to cinema, understood as animated pictures? Can the Nachleben of images, the migration of motifs, also be transported to the development of animated films?

Taking our cue from Warburg's final project, the Mnemosyne-atlas - 'an art-historical story-board' without any dominant linear narrative - the four case histories that follow are not ordered chronologically, and the temporal intervals between them are considerable. As on the pages of Warburg's atlas, each plate containing a combination of reproductions of works from different epochs and often different media, the intervals between the examples given allow for a new contextualisation of familiar imagery. As such, each case history is already part of the canon of animation, but 
the vantage point of iconology can suggest a new reading. The combination of these examples acknowledges the persistence of a visual language, throughout the technological transformation of the medium of animation, already present in the first description of a magic lantern by Christiaan Huygens in 1659 , demonstrating the illusion of movement through the appearance of a skeleton. ${ }^{6}$

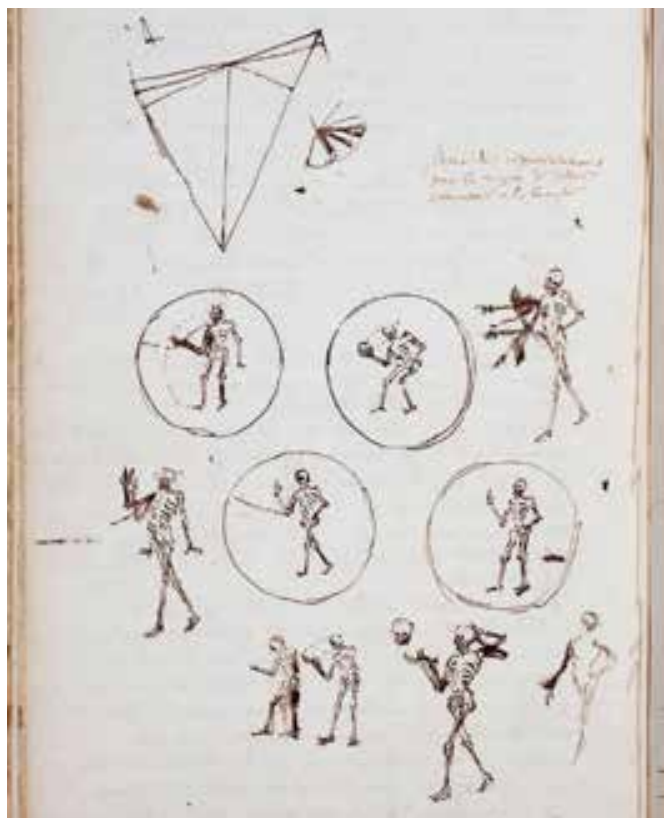

Christiaan Huygens' sketches (1659). Source: Leiden University Library, HUG 10 f076v https://socrates.leidenuniv.nl/view/action/nmets.do?DOCCHOICE $=2708936 . x m l \& d-$ $v_{s}=1349263583741 \sim 554 \&$ locale $=n l \&$ search_terms $=$ hug\%2010\&img_size $=$ best_fit\&adjacency $=N \&$ VIEWER_URL=/view/action/nmets.do?\&DELIVERY_RULE_ID $=1 \&$ usePid $1=$ true\&usePid $2=$ true

\section{Danse Macabre reanimated}

And so, using this framework: a skeleton at a feast or a feast of skeletons? Which is Gunning's most appropriate image to summon up the legacy of animated pictures? Can cinema indeed be understood as equivalent to a vanitas painting, a symbolic presence that betrays the shallowness of a whole event? Indeed, cinema focusses on the beauty of life, yet at the same time it is a strong reminder of the transience of things. Real life equals real time: an unregulated flow, not the undead, steady rhythm of fixated photographs, frozen moments controlled by technology. As a metaphor for the lingering situation of cinema at the brink of the 2Ist century, a 'feast of skeletons' sounds perhaps less morbid as an expression. What Gunning may have been hinting at with his conclusion is that we can inscribe the cinema in an even older tradition, a genealogy that reaches further back. His final sentences more specifically seem to suggest a comparison between animated pictures and the figural motif of the danse macabre. This medieval popular tradition was tolerated by the Church as a mural or picture book, for it was understood as warning against life's vanities, a wake-up call to 
adjust one's way on living in the light of the final judgement. However, most versions of the danse macabre demonstrate such a joy of living, with all their dance and music, they emanate so much energy with all their instruments and dance steps, that this rather suggests the opposite: a call to hedonism, to enjoy life while it is still possible.

Ambivalence is thus an inherent quality in any variation of the danse macabre: it evokes both dance and doom, vanitas as well as virtue. Within Western culture, the dance macabre occurs at the transition between the Middle Ages and the Renaissance, at a time when ecclesiastical doctrine of the Church clashed with scientific discoveries and new insights concerning both history and the cosmos. It was also between the I3th and the 15 th century that the age old idea of Purgatory, the interim state between one's death and a future resurrection, was being revived. The black plague of the I4th century further added an important connotation to the danse macabre.?

One of the key works, that pushed the artistic trope of the danse macabre in new directions is the series of woodcuts produced by Hans Holbein in I526. Instead of a collective procession of dancers, Holbein presents individual scenes from daily life. Death approaches its victims aggressively, without distinction of class or hierarchy. Because of this critical, 'subversive' approach, Holbein first published his work anonymously and without text in 1530 , then again in Lyon 1538 under the title 'Simulacres et historiées faces de la mort. ${ }^{8}$ As an indicator of an image that bears an ambivalent indexical relationship with reality, in French the term 'simulacrum' became so strongly identified with post-modernism and more particularly with Baudrillard (quoted by Gunning for the epigraph above his final chapter); in English, however, it had already been in circulation since the I2th century. The skeleton represents both a human figure and its opposite: a non-individual, generic representation. It stands for a figuration that is both real and virtual, that is both sketch and caricature.

How can a danse be macabre? And how can a skeleton appear to be dancing at all? Warburg demonstrated it this way: 'Attribution of movement. To attribute movement to a figure that does not move, it is necessary to awaken a series of images that link up one after the other - not an isolated image (kein einzelnes Bild): loss of calm contemplation'. 9 In what follows, the danse macabre serves as a topos that exemplifies an iconological consideration on the production of technologies of moving pictures, the significance and agency of images, and the transfer or migration of motifs. Examples from different eras of the history of the moving image serve as case studies, each one referring to the same visual trope of the danse macabre to demonstrate the potential of the medium: a Disney cartoon, a trick film documentary, a magic lantern performance and an early drawn animation film.

\section{Early cinema's vital energy}

One of the films that very likely haunted Gunning's mind is Disney's SKELETON DANCE (1929). More sophisticated than most silent film cartoons of that era, this macabre mini-ballet was produced as the first episode of the Silly Symphonies. Though the studio had just successfully experimented with synching music to animation the year 
before in STEAM BOAT WILLY (I928), SKELETON DANCE was the first film where, on the contrary, the image was entirely made to match a pre-recorded soundtrack. The visual theme for this film experiment came from the composer Carl Stalling, who was aiming at a perfect symbiosis of music and image. The hallmark of all Silly Symphonies became the evocation of inanimate figures such as trees and flowers coming to life and dancing to a humorous and rhythmic music, without any central character, that would recur in other films. ${ }^{\text {i }}$

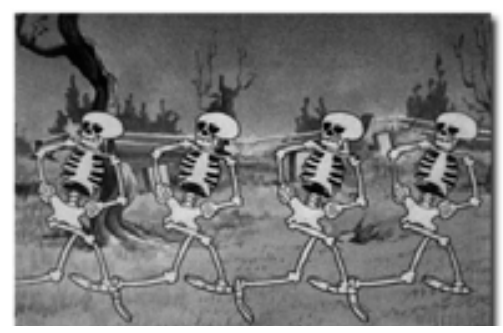

Still from SKELETON DANCE, Walt Disney (1929) http://www.disneyshorts.org/shorts.aspx? shortID=102

Disney standards, the animated ossuary and its cheerful choreography of surprisingly elastic performers remains a rare example of anarchic freedom of imagination. As a trial for a new series (soon imitated or even caricatured by MGm's Happy Harmonies and Warner Brothers' Merry Melodies and Looney Tunes) SKELETON DANCE was a prototype film not produced with any particular audience in mind. But the artists making this film did attempt to involve the viewer in provocative new ways. Not only is there the compelling synchronization of image and sound, but there are also purely visual attractions, such as a skull leaping towards the camera and swallowing it, by which the viewer feels warped into a universe where nature's laws are no longer univocally fixed. Stiff skeletons swaggle and dance the foxtrot, cats lose their fur, human bones are reshuffled to form music instruments: this transgressive feast of skeletons has all the characteristics of a Bakthinian carnival, with its typical reversal of order and values and the profanation of social hierarchies. This first Silly Symphony made explicit what would remain an implicit concept of the whole series: the ambition to offer entertainment that was silly yet serious at that same time; an audacious mix of high and low, vaudeville and classical music, a celebration of ambivalence, both funny and scary.

Both the musical and visual motif came from Stalling, ${ }^{\text {II }}$ but it was Disney's closest collaborator of that time, Ub Iwerks, who developed the idea and animated almost the entire film. Iwerks gave his imagination free reign to demonstrate what the medium of animation could do, bringing dead matter to life, and surpassing the laws of nature. No matter how unreal the scenes he evoked, the illusion was real: the viewer becomes pertinently aware that what he sees is a choreography of impossible movements. Apart from this perfect find - a feast of skeletons as a visual trope to demonstrate the potential of the medium - the film also resonates in a different way: it shows the iconological migration of a motif from one medium and epoch to another. The persistence of certain visual tropes is the core argument in Lynda Nead's The Haunted Gallery-Painting, Photography, Film c. 1900: 
'A figure comes back to life. It is the moment when the spatial and temporal separation of the viewer from the image breaks down and the secret life of the image is revealed once more. An animated figure never really casts off its previous doubts concerning its hold on life. The transformation might be reversed and the living portrait or statue be stilled once more. Thus the animated figure troubles the boundaries between life and death, nature and representation, movement and stasis, sensibility and lack of feeling. Its apparent ability to move between these states is the source of its uncanny and disturbing power over the viewer.' ${ }^{\text {I2 }}$

Describing the haunted gallery as 'essentially the setting for optical illusions and special effects, where people go to suspend their disbelief and to revel in the exquisite terrors of animation', Lynda Nead has pursued the Pygmalion motif from the classical period into the 2oth century and across different media. ${ }^{\mathrm{I} 3}$ Nead understands film as only one of many artistic formats possessed by cultural demons and phantoms. Without making it explicit, she combines iconography (the Pygmalion motif) with iconology as her methodology to investigate successive technologies that are able to animate dead images: 'This is the folded time of the haunted gallery, where living pictures and moving statues confuse past, present and future and in which new technologies express archaic, magical thinking. ' ${ }^{4}$

With a similar sense of paradox, the Disney studio thus chose an age-old pictorial motif to demonstrate their innovative use of sound. The question obviously remains whether Iwerks purposely referred to the medieval tradition of the danse macabre. In his study on the European influences Disney consciously integrated in his feature films, Robin Allen relates the imagery of SKELETON DANCE back to igth century Gothic melodrama.

'The ghosts and ghouls of popular legend were staple literary and illustrative diet from Dickens and his early illustrator George Cruikshank (I792-I878), to Poe and his gothic illustrators. (...) The film uses imagery of the ghost train or spookhouse of the fairground, where skeletons rise from tombs and cobwebs brush the visitor. Stalling also recalled a vaudeville act of skeleton dancers that he had seen as a boy.' ${ }^{\text {I5 }}$

In a footnote, Allen also refers the English pantomime tradition of an interlude with skeletons dancing continues to the day of his writing (I999), but he does not move beyond a British frame of reference. The tradition of dancing skeletons was however already documented in 1898 by the Lumière brothers in their LE SQUELETTE JOYEUX. ${ }^{16}$ Allen also overlooks a very British visual reference: the skeleton diving towards the camera and swallowing it as it were, was a remarkable stylistic jump that had already been demonstrated in THE BIG SWALLOW (I9OI) by the Williamson's Kinematography Company Ltd. THE BIG SwALlow shows an angry man who is so upset at being filmed 
that he swallows the camera operator and his camera whole. Enjoying the added power of animation, however, Iwerks makes us travel inside the rib cage and back out again. ${ }^{17}$ According to his biographer, Iwerks went for inspiration to the local library where he dug up illustrations by the British cartoonist Rowlandson and photographs of dancing skeletons on the walls of Etruscan tombs. ${ }^{18}$

As it concerned primarily a technological experiment, concrete art-historical references - let alone an allegorical moral content - were not likely the first concern of the creators of SKELETON DANCE. Perhaps it was Iwerks' own vanity to opt for such a challenging subject matter. The fact remains that it is hard to ignore the skeleton as an emblem, without any cultural connotations. As Gunning accentuated throughout his genealogical sketch of cinema's early evolution, and as Lynda Nead has also elaborated upon, in the early decades of the cinema, a paradoxical, but also very productive tension existed between technology and imagination, progressive enlightenment and age-old ritualistic energies. Or as Philippe-Alain Michaud puts it: 'With the beginnings of cinematography, the combination of threading and perforated film with the photographic impression, in restituting motion, was perceived figuratively as a symbolic victory over death - flooding both the spectator and the cameraman with very ancient animist reflexes'. ${ }^{19}$

As one of Warburg's immediate successors, Erwin Panofsky (1892-I968) was an early admirer of the cinema and was one of the first art historians to take the medium seriously as a heir to the legacy of medieval and renaissance art. His essay 'Style and Medium in the Motion Pictures,' originating from a talk for the New York Museum of Modern Art, has been widely considered for its notions of the stylisation of reality, but without paying proper attention to his remarks on animation: 'Within their self-imposed limitations the earlier Disney films, and certain sequences in the later ones, represent, as it were, a chemically pure distillation of cinematic possibilities. They retain the most important folkloristic elements - sadism, pornography, the humour engendered by both, and moral justice - almost without dilution'. ${ }^{\circ}$ As opposed to Warburg's focus on Renaissance arts, Panofsky's frame of reference is rather Medieval art, drawing useful parallels with folk art and all kinds of porcheria, not unlike the way Eisenstein also accentuated the ecstatic, erotic and proto-plasmatic qualities in the early Disney animation. ${ }^{2 \mathrm{I}}$ Slapstick, feeding upon the sadistic and the pornographic instinct, is how Panofsky describes the vital energy of early cinema, that was also manifest in the earliest Disney-productions, but was sanitized once the studio director started 'to endow film with higher values of a foreign order'. ${ }^{22}$

\section{Lanterns of fear}

When Aby Warburg founded his art historical method, focussing on the migration of visual motifs, he payed particular attention to the implicit movement. As Michaud points out: 'This iconology is based not on the meaning of the figures - the foundation of interpretation for Warburg's disciples, beginning with Panofsky - but on the interrelationships between the figures in their complex, autonomous arrangement, 
which cannot be reduced to discourse'. ${ }^{23}$ In I929, the year that SKELETON DANCE Was produced, Aby Warburg was writing in his journal about 'an iconology of intervals' ('eine Ikonologie des Zwischenraumes'), an experimental protocol he developed as part of his ultimate and unfinished project Mnemosyne. This was supposed to become an art historical atlas, with each plate containing a combination of reproductions of works from different epochs and often different media. Warburg, however, kept on reshuffling the reproductions and altering the combinations of his two-dimensional, dynamic memory theatre, to the extent that the book never went to production. Michaud gives the explanation that 'he had to renounce fixing the images, like a philosopher has to know how to avoid fixing his opinions. Thinking is a matter of plasticity, of mobility, of metamorphosis. ${ }^{24}$

During the reign of communism in his home country, the strategy of the Czech animator Jan Švankmajer was to constantly change style and medium, cleverly manoeuvring and outwitting the censors. Starting with a puppet theatre, he also took up graphic art, poetry, collage, ceramics and he kept on alternating these with other techniques. Although Švankmajer never received training as a filmmaker, he quickly achieved a strong reputation and thus got the assignment to make a documentary film for the centenary commemoration of František Rint's decorative art in the crypt of the Cistercian chapel at Sedlec (Kutna Hora) that contains somewhere between 50 and 70 thousand sets of skeletal remains. ${ }^{25}$ With his wife and children, the Czech wood-carver Rint completed this macabre folly in I870 as a memento mori to entertain visitors. Švankmajer's dense collage of shots in THE OSSUARY (I970) pays fitting homage to Rint's obsessive combinations of human bones into fascinating displays of shapes and objects, (including skull pyramids, crosses, a monstrance and a chandelier containing every bone of the human body). This is not an animated film in the strict sense, but nevertheless, it is made with the expertise of an animator, a unique collage in its play with rhythm both in the editing and within the image. Refusing to offer a comprehensive image of the location, Švankmajer exploits the suggestive cuts of his rapid editing and the intervals and discrepancies between sound and image, to produce an atmosphere of nervous tension. While demonstrating a fascination for the place, he creates a critique of the ideology of those commissioning both his work and Rint's. On several occasions, a long shot of the chapel's interior alternates with a frontal close-up of a skull, a perfect match-cut that sublimally suggests an equation between the Church and death, a hollow structure. Although all the images are

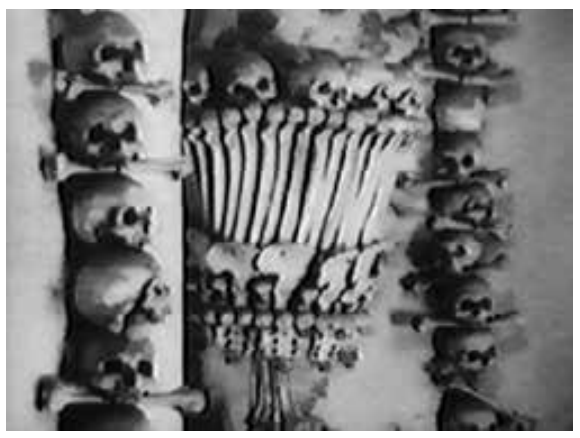
shot in situ, and the narrator's voice is that of a tour guide employed there, the institution commissioning his film forced Švankmajer to replace the soundtrack with a less conspicuous musical accompaniment. ${ }^{26}$

Still from THE OSSUARY [Kostnice] Jan Svankmajer, 1970 http://www.awn.com/heaven_and_ hell/svank/svank $9 . h t m$ 
With his background in the circle of Czech surrealists, Švankmajer is one of the first artists who understood animation more as a state of mind, and an aesthetic strategy, than a purely filmic effect. As a way of thinking in images, rather than as a filmic spectacle, as Michaud would put it. Švankmajer started by animating the puppet plays he was familiar with, allowing their dead limbs the freedom to enter a danse macabre-like performance. ${ }^{27}$ Claiming that objects spoke to him more than humans, Švankmajer often compared his methods with those of the shaman, conjuring dead matter to manifest itself in a very lively fashion on our sensorium. In HISTORIAE NATURAE, SUITA (I967) for instance he confronts us with visual conundrums such as a skull chewing on a steak or an egg entrapped in the skeleton of a bird, the ribcage replacing the familiar nest, using this type of morbid iconography to demonstrate the paradox that the anima - the spirit of life - is best evoked by its opposite: dead bones and mere matter.

The skeleton and, by extension, the danse macabre are age-old emblems of both our mortal destination (memento mori), as well as the mediators for illusory effect, or animation. In the history of the moving image, this ambivalence between death and afterlife, between the immobile and the animated has often been thematized, most notably from the start of the projected image. The earliest attestation of anything like a magic lantern dates from about I420: the Liber Instrumentorum by Giovanni de Fontana. It includes an illustration of a man holding a lamp (not yet a lantern with lenses), and on the wall is a large projected picture of the devil. The detail of the lantern shows the outline of a small image of the devil, suggesting the shadow figure as an enlargement. The most famous description of an early magic lantern stems from Athanasius Kircher, who included in the second edition of his Ars Magna lucis et umbrae (167I, printed in Amsterdam by Janssonius van Waesberge ${ }^{28}$ the image of a skeleton or the grim reaper henceforth appears time and again as the key signifier for the process of animating (= moving, resurrecting) still images.

The conflation of religious propaganda with the promotion of optical illusions was typical of the Counter-Reformation. As a Jesuit scholar and scientific luminary of his day, Kircher motivated his extravagant and sometimes even imaginary research by the ambition to propagate the true faith. Since the first magic lanterns appeared, the ambivalence between the epistemological and the illusory, magic and science, entertainment and enlightenment was an essential part of the fascination (as Švankmajer's The Ossuary reminds us). The lantern only received its epithet 'magic' in I668 from the Italian mathematician Francesco Eschinardi. ${ }^{29}$ Before that, it was often labelled 'the lantern of fear' (lanterne de la peur). Likely, because of this connotation, the most probable inventor of the magic lantern, Christiaan Huygens, preferred not to boast about this visual entertainment, as it might distract attention, or leave a less serious impression for his other research on lenses, telescopes, microscopes and clockwork..$^{30}$ For him, the notion of illusion was interesting only in so far as it implied that there is the opposite: true vision.

Traditionally, it is understood, that Kircher can not have been the actual inventor, as the accompanying depiction to the first printed mention of such a lantern demonstrates that he (or his illustrator) appears not to know precisely what he was 
doing: the grim reaper appears in the print in the same position on the slide as on the wall, whereas it should be turned upside down. Christiaan Huygens' sketches, on the other hand, are less elaborate in their evocation of a darkened room where a projection takes place. His furtive pen drawings are also less explicit in their religious meaning. His image of 'death at work bears no symbolic connotations, but all the better suggests movement and already implies the use of mechanical slides. In his notes of 1659 , we see schematic drawings of a skeleton waving its upper arm, and another one toying with its own skull. As an iconographic source, Huygens clearly used Holbein: his skeleton literally takes on the same poses as the one in Holbein's depiction of a skeleton visiting a doctor published a century earlier. Laurent Manoni, the author of The Great Art of Light and Shadow (its title a direct paraphrase of one of Kircher's books), mentions that in 1646 Christiaan Huygens painted a mural in his private garden, explicitly using figures from Holbein's Dance Macabre as his source of inspiration. ${ }^{3 \mathrm{I}}$

Both Gunning and Manoni take the position that the origins of contemporary cinema-culture are to be situated in the tradition of the magic lantern,,$^{32}$ but neither of them asks the iconological question why this new technology is being applied to such 'old' imagery. Manoni does not attempt to relate individual cases within his historiography, Gunning mainly accentuates the ambivalence between science and mystification. But a skull can, of course, stand for both: the skeleton is a traditional visual aid, in the doctor's cabinet as well as in the painter's studio. Marshal McLuhan famously proclaimed that the content of new media is usually derived from old media. ${ }^{33}$ With The Ossuary, Jan Švankmajer also translates the old image content of Kostnice into a novel form of animation, but at the same time, he reverses this paradigm by using old information to spell a new message. The real subject of his film is not the historical figure of the woodcarver Rint, who shaped the ossuary more than a century ago, but the invisible, anonymous tour guide on the soundtrack, with her obsessive call to order. It is in the elusive interstices between the autonomy of sound and image that Švankmajer articulates his ideas. We repeatedly hear the guide threaten school children with fines if they dare to transgress the rules of the institution. Her stifling voice becomes the emblem of an ossifying ideology that manages to mutate and migrate from one era to another.

\section{Expanded Magic}

Almost two hundred years before Švankmajer provoked the authorities with his suggestive animated documentary, Etienne-Gaspard Robert - a Belgian professor of physics who preferred to become a showman - was confronting the police in the days right after the French Revolution. With his magic lantern projections he appeared to reanimate the faces of some politicians of the ancien régime who had been recently eliminated. When Robert moved from his native Liège to Paris, he internationalized his name to Robertson and in the ruins of a Capuchin chapel, he started his séances with an improved magic lantern, essentially an expanded media show with the lantern 
behind a translucent screen. 1793 was the year the word 'phantasmagore' appeared for the first time as a name for the performer of the phantasmagorical shows. Before that, they were called nécromanciens. Not only did Robert change his name to the more international Robertson when he started organising pseudo-scientific variety shows, he also replaced the 'ph' of the already circulating word phantasmagoria with a simple ' $f$ ' to distinguish himself from his colleagues. On January 26th I799 Robertson applied for a patent for his own improvement of Kircher's magic lantern, which he then labelled as the 'fantascope'. It was a magic lantern on wheels with detachable lenses, one to project glass slides, the other to project opaque objects as a megascope. ${ }^{34}$

Robertson made his fame by inviting his audience to do requests. He resurrected people à la carte, with his magic lantern working as a guillotine in reverse. ${ }^{35} \mathrm{His}$ repertoire also included Egyptian motifs and themes from gothic literature. Following the French Revolution, more and more people became interested in the Middle Ages, considering it a kind of golden age, when the nation was not divided into small rival states, but unified by Christianity. The romantics not only discovered medieval culture, but also the power of the subconscious and the supernatural: nightly ghosts and the dance of death. The French revolution radically changed politics, society and economy, and thus also the spheres of culture and religion. It even led to a boom in danses macabres. ${ }^{36}$

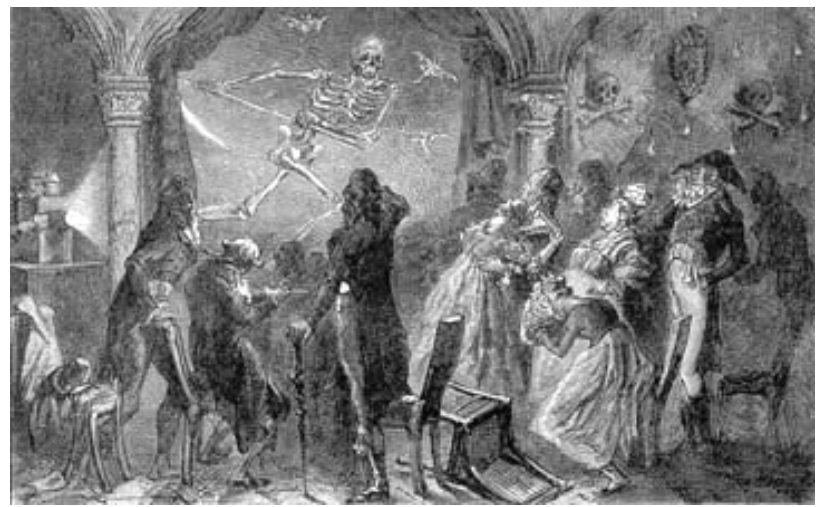

Fantasmagorie, Robertson ca, 1794

http://www.precinemahistory.net/1750.htm

There are thus a number of reasons to explain why the skeleton played such a central role in fantasmagoric shows. Robertson systematically depicted a skeleton when he had posters printed for his fantasmagoric shows, the competition followed his example. The lanternists and phantastmagorians of the eighteenth century no longer addressed the religious realm, but rather the profane, and more in particular: the paying public. In the process of all this popularization of new technology, the impact became less and less macabre, and the entertainment value increased. Audience appeal was situated more in the technological feat of rendering a holographic image - that could even be projected on smoke - than in the fearsome evocation of death 
or the Devil. With his megascope, Robertson was able to project a skeleton rising from his grave in $3 \mathrm{D}$, with a figure carved out of ivory. The audience was startled, yet it was reminded by Robertson this appearance was merely an illusion that could be resurrected at will.

Once Robertson exhausted his success in Paris, he started to perform in other cities and countries, as far as Russia. The concept of the phantasmagoria also migrated on its own, and its Nachleben became an metaphor that appeared useful for both Karl Marx and Walter Benjamin, for Emile Zola as well as Arthur Rimbaud - each displacing the meaning of the word in a different way. The literary historian Max Milner considers the term very typical for that particular era, when the creative imagination became aware of the paradoxes and contradictory connotations included in the word. ${ }^{37}$ Tom Gunning considers it similarly: 'a term in tension, phantasmagoria takes on the weight of modern dialectics of truth and illusion, subjectivity and objectivity, deception and liberation, and even life and death. ${ }^{38}$

As a more technological term, on the other hand, the notion of fantascope and phantasmagoria lived on in the work of audiovisual innovators such as Joseph Plateau, Armat \& Jenkins, and T.W. Naylor. ${ }^{39}$ The persistence of the term phantasmagoria or variations thereof, illustrates how strongly the impact of Robertson's magic lantern performances lingered, and that the ambition of subsequent innovations remained the same: to provoke the appearance of phantoms by technological means. The instrument Plateau invented in I832 to demonstrate the supposed retinal afterimage, he initially named the 'phenakistiscope', but his London publisher, who began to sell the rotating discs commercially the following year, decided for the first edition on 'phantasmascope' and for the second edition on 'fantascope'. In I866 L.S. Beale invented the choreutoscope, a mechanical magic lantern slide that could show several frames consecutively. The best-known application is a skeleton removing its own head, very much like the action already sketched out by Huygens. The effect was based on the first application of the Maltese cross for transporting film (in this case a glass plate), thirty years before several pioneers of the cinema would apply the same principle to their prototype cameras.

One year before the Lumières introduced their photographies animées (as they usually described them), the experimental researcher physiologist Étienne-Jules Marey published graphic schemes of a stickfigure in action in his book Le Mouvement (I894). Reducing a running man to a constellation of a mere few white lines on a black background, 'the figure is conceived not as a modification or a state but as a manifestation of energy,' as Michaud puts it. ${ }^{40}$ Marey's ambition was not to reproduce movement, but to render it graphically as a kind of score, that could be analyzed and mentally activated by a trained eye. For his Mnemosyne, Warburg required a similar participatory approach from the viewer. Avoiding all textual commentary, this 'haunted story for grown-ups' ('eine Gespenstergeschichte für ganz Erwachsene') relies entirely on the analytical skills and the cultural memory of its public. Movement is essential for Warburg, but one that is completed by the viewer, who is expected to animate the intervals. As opposed to Panofsky, Warburg did not define meaning within the image, but in between images. 
This was also the philosophy behind the rostrum camera, the essential machine of Canadian animator Norman McLaren. He is most often cited for the motto he kept above his animation stand: 'Animation is not the art of drawings that move, but the art of movements that are drawn. What happens between each frame is much more important than what exists on each frame. Animation is therefore the art of manipulating the invisible interstices that lie between the frames. ${ }^{31}$ Approaching art via interstices, is a productive paradox in line with Warburg's non-explicit transitions between his photographic reproductions, as well as with Marey's obsession to render life without halting it. To mediate movement without deviation, he switched from graphic techniques to photography, yet retaining the abstract qualities of his prior results thanks to the 'exoskeleton,' the black suit with white stripes he continued to put on his subjects.

Since Joseph Plateau, the basic premise for any animation has remained that the physiological participation of the viewer is crucial to experiencing an illusion of movement. Warburg extended this and situated the development of art movements as a process that can only be hinted at through the cultural memory of the beholder.

\section{A visual matrix}

Georges Didi-Huberman describes how the black zones in Warburg's Mnemosyne panels give the combined photographs a 'milieu' and allow transitions to take place. He considers them essential components of the puzzle: "The "milieu" can be understood as the interval that happens between the images, these "details" or "monads" of each panel. The interval manifests itself first of all in the fringes that separate the photographic prints: they often form large empty zones of black cloth'. ${ }^{2}$ PhilippeAlain Michaud goes even further and observes how the black backgrounds on which the play of the sequencing and displacement of images is organized serve the same function as the space described by Dickson in his first films created against the backdrop of the Black Maria: an isolating function concentrating on movement and apparition.' 43
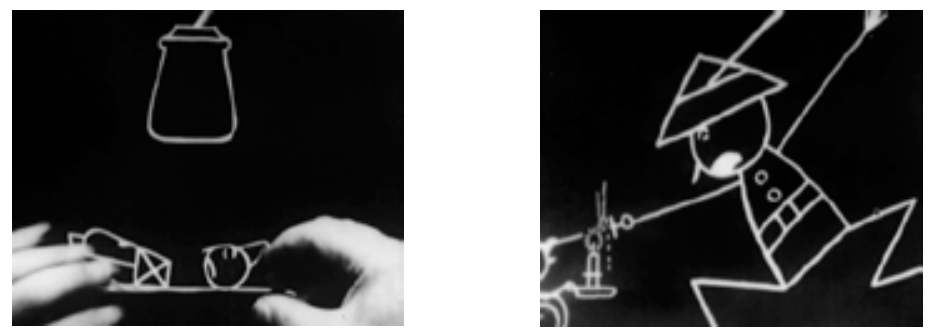

FANTASMAGORIE, Emile Cohl, 1908. Stills from DVD Emile Cohl (Gaumont 2008)

When Emile Cohl conceived his first animated film in I908, FANTASMAGORIE, he opted for a similar black background as an activating platform. The technique he used was simple, and already familiar from the genre of the phantom ride movies: he used the 
negative in stead of the positive image of his filmed drawings, made with black ink on white paper. In reverse, the white lines seem to appear on a blackboard, emulating the performance of graphic artist, a familiar ingredient of vaudeville shows of that era. If Méliès can be understood as the last stage magician, then Cohl might be deemed the final lightning sketcher, with his automation of live drawing. Fantasmagorie has been labelled the first animated cartoon, as indeed - apart from a few shots where the hand of the invisible creator enters the screen - it is entirely made up of drawings that appear to move autonomously. There were, however, several precedents to Cohl's debut, particularly trickfilms involving the stop-motion animation of objects. In I900 Stuart Blackton had already made ENCHANTED DRAWING, followed in I9O6 by his HUMOROUS PHASES OF FUNNY FACES, both starting off explicitly as the recording of a lightning sketch or 'chalk talk' performance. ${ }^{44}$ But FANTASMAGORIE is the first film where this documentary contextualisation is absent, and where the lively movement of the line drawings is more important than the figuration. For Emile Cohl, action was more important than representation, or as Panofsky would put it: animation is about space and time, not about the human figure. 45

The images Cohl evokes are not abstract, however, and their fast mutations illustrate a bizarre stream of consciousness at work. Despite a duration of less than two minutes, the plot of FANTASMAGORIE is hard to summarize, given the constant shift of the scenes. A sketchy protagonist (with no more details than a stick figure) gets involved in several skirmishes. All the objects he encounters are caught in a free flow of associative, rapidly transforming images. Although Cohl inevitably lacked experience while animating FANTASMAGORIE, the stunning pace and bizarre accumulation of rudimentary pictograms might have been the consequence of a certain lack of control over his first film. But the sheer absurdity of his short scenes suggests that Cohl did not intend to impose a single understanding of his irrational narrative. FANTASMAGORIE's assembly of oneiric situations escapes the viewer, and both liberates him or her to come up with a very personal interpretation.

Didi-Huberman describes how the Mnemosyne atlas 'offers less a pre-existing interpretation on the transmission of images, than it accords a visual matrix to multiply possible orders of interpretation..$^{6}$ Just as a collage imposes the need for active interpretation, so does the combination of pictures on a Mnemosyne board. Similarly, animation is a format which accumulates film frames, and functions through combinatorial aesthetics, linking individual frames in order to experience movements that only exist in the mind of the beholder. Collage aesthetics abound in Emile Cohl's often stunningly hybrid films where a clash of techniques is the main attraction. In titles such as TRANSFIGURATIONS (I909) LES GÉNÉRATIONS COMIQUES (I909), L'ENFANCE DE L'ART (IgIO) Or LES BEAUX-ARTS MYSTÉRIEUX (I9IO) Cohl is combining drawn animation with cut outs, object animation, puppet animation, split screen, hand tinting etc.

With the title of his very first film FANTASMAGORIE Cohl clearly inscribes himself into the tradition of Robertson, Plateau and many others, who used the prefix 'fanta-' to allude to the ghostly aspect of the animations they produced. Cohl's artificial appearances are more a kind of drunken hallucination than a horror movie. Shortly afterwards, Cohl realised Le CAUCHEMAR DU FANTOCHE (I9O8) and DRAME CHEZ LES FANTOCHES 
(I908) that suggests there was clearly a sense of method behind his madness. As a prototypical film, FANTASMAGORIE was thus not only technically the first film consisting (almost) entirely of drawn animation, it was also the first animated cartoon in film history with a recurring character: Fantoche. Cohl even finished his prolific filmmaking career with a last adventure of his favorite persona: LA MAISON DU FANTOCHE (I92I).47

In French popular culture, a fantoche stands for a puppet, a person without a proper will, a clown, a mannequin, a simulacrum or a zombie, among many more connotations..$^{8}$ Hence, the title Fantasmagorie can be simply understood as an assembly of fantasies involving the central character Fantoche, but it can also be interpreted as a deliberate historical reference to Robertson's phantasmagoric performances. One scene in particular reminds us of the 'guillotine working in reverse': halfway through the film, Fantoche is suddenly decapitated, and then a human hand (Cohl's) glues his head back on his ephemeral body. Stylistically, the scene represents a sudden rupture in the string of actions. It is also quite literally an emblematic scene, as very likely this was Emile Cohl's way of signing his own work. He even explicitely shows the viewer a pot of glue. Pronounced in French, 'Cohl,' the pseudonym of Emile Eugène Jean Louis Courtet, is homophonic to the word glue or 'colle'. This rebus-like method of signing a work had already been demonstrated by Hans Holbein in his painting The Ambassadors (1533), where a hollow bone in the anamorphic shape of a skull presents the viewer with a riddle.

Decapitation could have been the motif for a panel within the Mnemosyne atlas: from Huygens first sketches of a skeleton juggling its own head, to the choreutoscope automating this sinister gesture, to the old logo of the Annecy festival (the world's most prominent festival for animation film). Although Aby Warburg's main interest always remained Renaissance culture, he also took a serious interest in the folk art and rituals of the Pueblo Indians, and included in his panels advertisements and stills from popular films as well. Iconology, as envisioned by Warburg, was supposed to study images produced inside and outside of the realm of art. In order to trace the meanings, histories and transformation of images, he conceived iconology in essence as interdisciplinary and diachronic.

When in 1908, Cohl entered the film industry, he already had several careers behind him: as a graphic artist, an editor of a journal, a theatre writer and actor, and a photographer, among other activities. ${ }^{49}$ For the first three decades of his professional life, Cohl was a familiar face in the bohemian world around Montmartre. He was a leading member of the Incohérents, a shortly lived anarchic proto-Dadaist movement (1883-1887) which mocked all academic art, in particular Symbolism and Impressionism. The visual puns and childlike drawing style in FANTASMAGORIE and the skeletal-like appearance of Fantoche are clearly resonant of that earlier period. A close friend of André Gill, Cohl was a very gifted caricaturist with strong graphic skills. Allegedly because Gaumont was clearly plagiarizing him with one of their film posters, Emile Cohl stepped into their film offices, and thus into film business. In its opening scene, FANTASMAGORIE clearly addresses the context of the cinema experience of the time, and the anthology of events that follow can also be understood as caricaturing the tropes of early slapstick. 
FANTASMAGORIE abounds in conflicts, rebellious fights and even a traditional duel..$^{\circ}$ The main theme of the film, however, remains death and resurrection. The cinema theatre in FANTASMAGORIE is a haunted gallery, a place for the undead, where skeletal figures perform their danse macabre and remind us that what we are watching is not living, not still, but a spectacle of 'undead' movements.

Working largely by himself, Cohl's écriture automatique rapidly lost impact once the animation industry became automated, and targeted commercial expansion. Just as the craftsman Georges Méliès lost the battle with the booming film industry, so did Cohl. His type of subversive, singleminded, deregulating filmmaking migrated to the world of artistic avant-gardes, where iconoclasts such as Fernand Léger (BALLET MÉCANIQUE, I924) ) $^{51}$ and Marcel Duchamp (ANÉMIC CINÉMA, I926) 52 adopted this rebellious kind of animation and took it to the gallery and museum world.

Lynda Nead uses the haunted gallery as a powerful metaphor for the uncanny magic of early film. Every still frame is haunted by the photographic likeness of those who are no longer there; each time the projector is set in motion the figures step out of their frames and come to life. Animation enchants the viewer in an even deeper way: 'Like the form of the ancestral ghost, animation disturbs chronology, drawing the past into the present and reintroducing pre-modern beliefs to modernity.' 53 The enduring fascination of the trope of the haunted picture gallery lies, in part, in its mutability and adaptation to new forms of visual media. 'Successive technologies demonstrated their magical properties through their power to animate the dead image.'54 Or to paraphrase Tom Gunning: There is always a future, only seemingly an apocalyptic one, for this century-old illusion.

\section{Notes}

I Tom Gunning: “Animated Pictures', Tales of Cinema's Forgotten Future', Michigan Quarterly Review, vol. 34, no. 4 (Fall i995), p. 483

2 See for instance Lev Manovich Language of New Media, MIT Press, Massachussets 200 I.

3 For Warburg Nachleben first of all implied the research into the survival of forms and practices from the classic Greek and Roman era. For an interpretation of Nachleben as an anthropology of time, see: Georges Didi-Huberman, L'image survivante - histoire de l'art et temps des fantômes selon Aby Warburg, Les Editions de Minuit, Paris 2002, p. $5 \mathrm{I}-60$.

4 See: Didi-Huberman, L'image survivante and also: Philippe-Alain Michaud, Aby Warburg and the Image in Motion, Zone Books, London 2004.

5 (Own translation) from: Philippe-Alain Michaud, Sketches - Histoire de l'art, cinema, Kargo \& L' Éclat, Paris 2006, p. 7: 'Avant même d'être un dispositif technique et spectaculaire, le cinéma est une manière de penser les images. C'est ainsi que dans les deux premières décennies du $\mathrm{XX}^{\circ}$ siècle, Aby Warburg invente in histoire de l'art, loin de l'industrialisation du cinéma et de sa transformation en culture de masse, un style d'analyse des images fondé sur les propriétés du montage et du défilement qui trouvera à la fin des années I920, dans le projet inachevé de Mnemosyne, son élaboration ultime: les séries de Pathosformeln que Warburg agence sur les planches de son Atlas sont des object cinématographiques - les story-boards de sa pensée.'

6 A similar approach, the study of topoi, is propagated by Erkki Huhtamo, who applies the ideas of art historian Ernst Robert Curtius to the notion of media archeology. See his essay 'Dismanteling the Fairy Engine: Media Archeology as Topos Study' in the book (E. Huhtamo \& J. Parikka, eds), Media Archeology: approaches, applications and implications, University of California Press, Berkeley 20II, p. 27-47.

7 The oldest, monumental danse macabre is situated in the Cimetière des Innocents (Paris, I424-I425). Some 
of the earliest danses macabres are to be found in Germany and Spain (eg. I460 'La Danza general de la Muerte'). For both general information and specific descriptions, see, for instance, the series L'Art Macabre, the yearbook published by the European Association for Danses Macabres; edited by Uli Wunderlich, Düsseldorf.

8 See: Hans Holbein, The Danse of Death - 41 woordcuts by Hans Holbein the Younger - Complete Facsimile of the Original 1538 French Edition. Dover Books, New York I97I. In 1545 another eleven engravings were added to the original forty-one engravings, including accompanying texts.

9 (Own translation) Didi-Huberman, L'image survivante, p. 484: 'Attribution du mouvement. Pour attribuer du mouvement à une figure qui ne se meut pas, il est nécessaire de réveiller une suite d'images qui s'enchaînent les unes aux autres - pas une image isolée (kein einzelnes Bild): perte de la contemplation calme.'

Io In the end, the Silly Symphonies turned out a series of 75 films. The major exception in these were the characaters of the three little pigs, recurring four times. The Silly Symphonies were the platform for Disney artists to experiment with new techniques, such as the multi-plane camera, the first color short and the first attempt at animating realistic human figures, before Snow White was produced.

II The xylophone piece in the music score have led many to wrongly appoint the piece as Saint-Saëns Danse Macabre, the composer Carl Stalling however adapted parts of Edvard Grieg's The March of the Trolls.

I2 Lynda Nead, The Haunted Gallery- Painting, Photography, Film c. 1900, Yale University Press, London 2007, p. 46.

I3 Nead, The Haunted Gallery, p. 49.

I4 Nead, The Haunted Gallery, p. 47.

I5 Robin Allen, Walt Disney and Europe - European Influences on the Animated Features of Walt Disney, Indiana University Press, Bloomington I999, p. 25.

I6 Le Squelette joyeux, I898 (Lumière catalog number 83I), see: Jacques Rittaud-Hutinet, Auguste et Louis Lumière - les 1000 premiers films, Philippe Sers Editeur, Paris 1990, p 56.

I7 A similar effect is repeated in HeLL's BeLLS, another spooky Silly Symphony from I929.

I8 Leslie Iwerks \& John Kenworthy, The Hand behind the Mouse - an intimate biography of Ub Iwerks, Disney Editions, New York 200I, p. 76.

I9 Michaud, Aby Warburg and the Image in Motion, p. 47.

20 Erwin Panofsky, 'Style and Medium in the Motion Pictures', in: Gerald Mast \& Marshall Cohen (eds.), Film Theory and Criticism: introductory readings, Oxford Press, London 1974, p. I60. An early version was enunciated as a lecture for the Metropolitan Museum of Art in 1936, but it was Irish Barry who has solicited Panofsky to support the founding of a film department at the Museum of Modern Art in New York. Panofsky often reprised and at times revised the contents of the lecture. Media theoretician Thomas Levin wrote an excellent analysis of his text, indicating the many stages it went through from a first publication in 1936 till the most often reprinted version of 1947 . See: Thomas Levin, 'Iconology at the Movies - Panofsky's Film Theory', The Yale Journal of Criticism, 9.I (I996) p. 27-55. Consulted via: http://muse.jhu.edu/demo/yale_journal_of_criticism/9.Ilevin.html

2I See also Sergej Eisenstein, 'Eisenstein on Disney', Seagull Books, London I986. Eisenstein recurrently wrote on animation during the time he worked on his unfinished book The Method.

22 Panofsky, 'Style and Medium in the Motion Pictures', p. I54. Most of his thoughts on animation are to be found in an unusually extensive, passionate footnote, that must date from one of the later versions of the essay, as Panofsky also refers to FANTASIA (I940).

23 Michaud, Aby Warburg and the Image in Motion, p. 252.

24 (Own translation) Michaud, Sketches, p 46o: 'il devait renoncer à fixer les images, comme un philosophe doit savoir renoncer à fixer ses opinions. La pensée est affaire de plasticité, de mobilité, de métamorphose.'

25 After I 400 one of the abbots had a church of All-Saints erected in Gothic style in the middle of the cemetery and under it a chapel destined for the deposition of bones from abolished graves, a task which was begun by a half blind Cistercian monk after the year I5II. The charnel-house was remodelled in Czech Baroque style between I703 I7Io by the famous Czech architect, of the Italian origin Jan Blažej. See the official site of the Sedlec Ossuary. http:// www.ossuary.eu/index.php/en/ossuary

26 The voice of the female amateur tourist guide was replaced by a female vocalist singing (in Czech) the surrealist poem by Jacques Prévert, 'Pour faire le portrait d'un oiseau' ('To Paint the Portrait of a Bird'). Only after the velvet revolution was the original soundtrack reinstated.

27 Švankmajer's early puppet films (that tie in with the Czech tradition of ideological resistance and national revival, as the marionette puppet theater was the only place were culture in the native language was allowed during the Habsburg reign) comprise the following titles: THE LAST TRICK (his film debut, 1964), PUNCH AND JUDY (1966) and DON JUAN (I970).

28 For further reference of Kircher's works printed in Amsterdam see: Paul Begheyn S.J., Uitgaven van 
Jezuiten in de Noordelijke Nederlanden 1651-1700. Consulted via http://www.dbnl.org/tekst/_zevooII9980I_or/_ zevooII9980I_OI_ooI2.php

29 See Laurent Manoni, The Great Art of Light and Shadow - Archeology of the Cinema, University of Exeter Press, Devon 2000 , p. 55 .

30 Requested by his father to produce a lantern for demonstrations at the Louvre, Christiaan Huygens feigned to have lost the formula. See Manoni, The Great Art of Light and Shadow, p. 4I.

3I See Manoni, The Great Art of Light and Shadow, p. 39.

32 For a clear statement on the conceptualisation of cinema, independent from the materiality of film, see for instance the subtitle in: Laurent Manoni, Lanterne magique et film peint: 400 ans de cinéma, Editions de la Martinière, Paris 2009 .

33 See Marshall McLuhan, Understanding Media, MIT Press, Massachussets I994, p. I8.

34 Over the last decade, many authors have written essays on the historical aspects of the fantasmagoria, but the most thorough introduction to Robertson and his activities remains: Françoise Levie, Étienne-Gaspard Robertson. La vie d'un fantasmagore, Le Préambule (Collection Contrechamp) I990.

35 For a parallel between the origins of the fantasmagoria and the wax museum of Madame Tussaud, see: Edwin Carels, 'Résurrection à la Carte', in: Eric Kluitenberg (ed.), The Book of Imaginary Media - excavating the dream of the ultimate communication medium, Nai Publishers, Rotterdam 2006, p. I86- 213.

36 Uli Wunderlich, 'Säkularisierungstendenzen seit der Aufklärung,' in: Uli Wunderlich (ed.), Der Tanz in dem Tod - Totentänze vom Mittelalter bis zur Gegenwart, Eulen Verlag, München 200I, p IоI.

37 Max Milner, La Phantasmagorie - essay sur l'optique fantastique, Presses universitaires de France, Paris I982.

38 'I know of no word more complex than 'Phantasmagoria", in: Tom Gunning, 'Illusions Past and Future: The Phantasmagoria and its Specters' (2004), a text for the First International Conference on the Histories of Art, Science and Technology, consulted via www.MediaArtHistory.org

39 For further specifications, see Edwin Carels, 'Résurrection à la Carte', p. 207.

40 Michaud, Aby Warburg and the Image in Motion, p. 88.

4I Georges Sifianos in 'The Definition of Animation: A Letter from Norman McLaren,' in: Animation Journal, vol. 3, no. 2, spring 1995 , p. 62.

42 (Own translation) Didi-Huberman, L'image survivante, p 496: 'Le 'milieu' peut être entendu comme l'intervalle qui a lieu entre les images, ces 'détails' ou 'monades' de chaque planche. Lintervalle s'y manifeste d'abord dans les bordures qui séparent les tirages photographiques: elles forment souvent de grandes zones vacantes de toile noire.'

43 Michaud, Aby Warburg and the Image in Motion, p. 244.

44 As with the general history of invention of motion pictures, neither can there be a single inventor be pointed out for the technique of animation. Although some French authors such as Bernard Génin and Pierre Courtet-Cohl in their book Émile Cohl - linventeur du dessin animé (Omniscience publishers, 2008, Sophia-Antipolis, France) proclaim Cohl to be a pioneer on almost every account, it is clear he was not the first to use object, cut out, puppet or clay animation. Yet no animator of his time applied such a variety of techniques, often within the same film. And he did invent the rostrum camera and was the first to include scratching on film stock as a graphic technique.

45 See Panofsky, 'Style and Medium in the Motion Pictures', p. I6o: 'their fantastic independence of the natural laws gives them the power to integrate space with time to such perfection that the spatial and the temporal experiences of sight and hearing come to be almost interconvertible.'

46 (Own translation) Didi-Huberman, L'image survivante, p 464: 'L'atlas Mnémosyne illustre moins une interprétation préexistante sur la transmission des images qu'il n'offrirait une matrice visuelle pour en démultiplier les ordres possibles d'interprétation.'

47 In 2008 , to celebrate the centenary of FANTASMAGORIE, the French Cinémathèque presented a conference with a complete retrospective of all the retraced films by Emile Cohl. To that date however, these accounted for only 65 from a filmography of more than 300 titles.

48 The following definitions can be found for 'fantoche' in French: 'harlequin, automate, bidon, clown, fantoccini, girouette, inconsistant, inexistant, mannequin, marrionnette, pantin, polichinelle, poupée, sauteur, simulacre, zombi'. Source: http://dictionnaire.sensagent.com/fantoche/fr-fr/

49 Furthermore, Cohl was also an early adaptor as a cyclist and philatelist. For a biographical sketch, see: Donald Crafton, Emile Cohl, caricature and film, Princeton University Press, Princeton NJ 1990.

50 A biographical motif, as Cohl himself once entered a duel, see Crafton, Emile Cohl, p. 4I (another duel, I886).

5I See: http://www.youtube.com/watch?v=H_bboH9piYs

52 See: http://www.youtube.com/watch?v=dXINTf8kXCc

53 Nead, The Haunted Gallery, p. 47.

54 Nead, The Haunted Gallery, p. 82. 